\title{
The Application of Biofiltration with Polyurethane Foams for Domestic Sewage Treatment
}

\author{
Ewa Dacewicz' \\ 1 Department of Sanitary Engineering and Water Management, University of Agriculture in Kraków, \\ al. Mickiewicza 24/28, 30-059 Kraków, Poland \\ e-mail: ewa.wasik@urk.edu.pl
}

\begin{abstract}
The study presents the results of an experimental method for purification of household sewage on the biofilters filled with polyurethane waste in the form of trims of upholstery foam (PUF). We assessed the removal effectiveness of organic compounds, ammonium nitrogen and total suspended solids from sewage pre-treated in a septic tank at hydraulic loading ranging from 31.8 to $229.2 \mathrm{~mm}^{-1}$. The results of five month study identified the biofilter

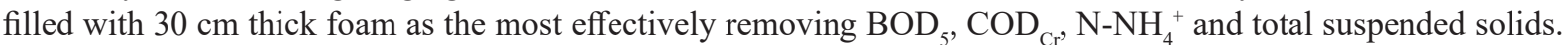
Average reduction in pollutant levels for this filter reached $95 \%, 94 \%, 84 \%$ and $68 \%$, respectively. PUR foam in the form of trims of upholstery foam filling the vertical flow filters ensured favorable conditions for the development of heterotrophic and nitrifying bacteria without any need for additional aeration.
\end{abstract}

Keywords: waste, polyurethane foam, sewage treatment, biofilter

\section{INTRODUCTION}

For a long time now, fast developing countries have faced an issue of untreated household sewage discharged directly to the environment. An inadequate infrastructure for water supply and sewage removal increases the risk of diseases spreading amongst the people exposed to unsafe water. In 2015, the World Health Organization reported that 127 million people used basic services, 263 million used limited services, 423 million used unimproved sources and 159 million used surface water [UNICEF, WHO...2017]. The insufficient hygiene and sanitation related to the above-mentioned problem resulted in million people deaths. The access to safe water and sanitation are essential to human health and to the environmental sustainability and economic prosperity.

With the increasing cost of electricity, it is important to conduct sustainable wastewater treatment process management. For aerobic wastewater treatment with activated sludge the aeration process may consume up to $60 \%$ of the total WWTP power demands [Gikas 2017].
In the case of on-site sewage treatment, effective and economical solutions must be proposed. Easy to use technologies that have low energy demand should be used. The technologies that do not require energy inputs e.g. for additional aeration, can be an example.

One of the popular on-site sewage treatment systems is a combination of a septic tank and a vertical flow sand filter [Chmielowski and Ślizowski 2008, Wąsik and Chmielowski 2017, Dacewicz and Chmielowski 2018, Wąsik and Chmielowski 2018]. It yields good results and is inexpensive but its main disadvantage is the possible silting up of the filter bed. Sand-filled filters are also poorly aerated due to a low content of the empty fraction.

In order to increase the removal rate of organic and biogenic compounds and to prevent the filter from silting up, the sand filling may be replaced, partly or completely, with porous materials. The adsorption capacity of porous materials depends on an internal system of pores of different sizes. Natural porous materials commonly used to treat water and sewage include clay [de Gisi et al. 2016, Dacewicz and Chmielowski 
2018], chitosan [Ali 2012, de Gisi et al. 2016] and zeolite [Ali 2012, de Gisi et al. 2016, Dacewicz and Chmielowski 2018].

Natural materials may be replaced with plastic fillings that feature equally large specific surface area but tend to clog less. An interesting solution is using materials of porosity exceeding $90 \%$, e.g., foams made of polyurethane or polyethylene. In the 1990s, professor Hideki Harada et al. from the Nagaoka University of Technology in Japan used a downflow hanging sponge (DHS) system for sewage post-treatment. Sponge cubes hanging freely in the air, called "first-generation DHS" were used to treat the effluents from an anaerobic reactor UASB. To date, extensive studies focused on the use of six generations of the DHS technology for treatment of low strength wastewater [Tawfik et al. 2008, Tawfik et al. 2010, Tawfik and Klapwijk 2010, Miyaoka et al. 2017]. In order to prevent the deformation of the flexible foams and their adhering to each other, they were packed in plastic sheaths, starting with the DHS-G3 generation. The sixth generation systems use rigid polyethylene foams manufactured by copolymerization with an epoxy resin [Onodera et al. 2014].

DHS reactor has many advantages but it cannot be used for treatment of raw sewage containing high levels of suspended solids (SS). Their presence in fluids flowing through the foams prevents oxygen and substrates from supplying the biofilm [Guo et al. 2010]. Therefore, it is recommended to remove larger suspended matter and solids before the sewage enters the DHS reactor. Uemura et al. [2012] investigated the direct treatment of settled sewage using an independent DHS system. They used foams with pores of different sizes, enabling the reduction of COD by $83-85 \%$ $\pm 12 \%$, and of ammonium nitrogen by $90-95 \%$ $\pm 13 \%$. Ehsas [2013] used a laboratory-scale in- dependent DHS system to treat synthetic sewage (tap water with dog feed added). With cylindrical polyurethane foams randomly packed into the reactor modules, the pollution reduction ranged from $56-76 \%$ for $\mathrm{COD}, 58-91 \%$ for $\mathrm{BOD}_{5}$, $83-100 \%$ for ammonium nitrogen, and $58-97 \%$ for total suspended solids. Tawfik et al. [2011] used the DHS system with randomly packed foams to treat gray sewage. They achieved the removal of COD, ${\mathrm{N}-\mathrm{NH}_{4}+}^{+}$and total suspended solids at a level of $90-96 \% \pm 2 \%, 26.7-86 \% \pm 13 \%$ and $93.5-98.2 \% \pm 1 \%$, respectively.

This article discusses a possibility of using plastic waste in the form of polyurethane foams for purifying household sewage after pre-treatment in a primary sedimentation tank. It also presents a correlation between the filter thickness and effective removal of organic compounds, nitrogen compounds (in form of ammonium nitrogen) and total suspended solids on biofilters working under variable hydraulic loading.

\section{MATERIAL AND METHODS}

The biofilters were filled with trims of flexible polyurethane foam of random shapes, supplied by Eurofoam Polska (Fig. 1), used commercially as upholstery foam. They featured high porosity of 94.6\% [Dacewicz 2018a].

Figure 2 shows a granulometric curve plotted based on the weight of foam pieces retained on individual sieves of a shaker for loose soils. Nominal diameters, $\mathrm{d}_{10}$ and $\mathrm{d}_{60}$, read from the curve, of $4 \mathrm{~mm}$ and $10 \mathrm{~mm}$ (similar to a gravel) (PN_EN ISO 14688-1), respectively, were used to calculate the coefficient of graining non-uniformity $\left(\mathrm{d}_{60} / \mathrm{d}_{10}=2.5\right)$.

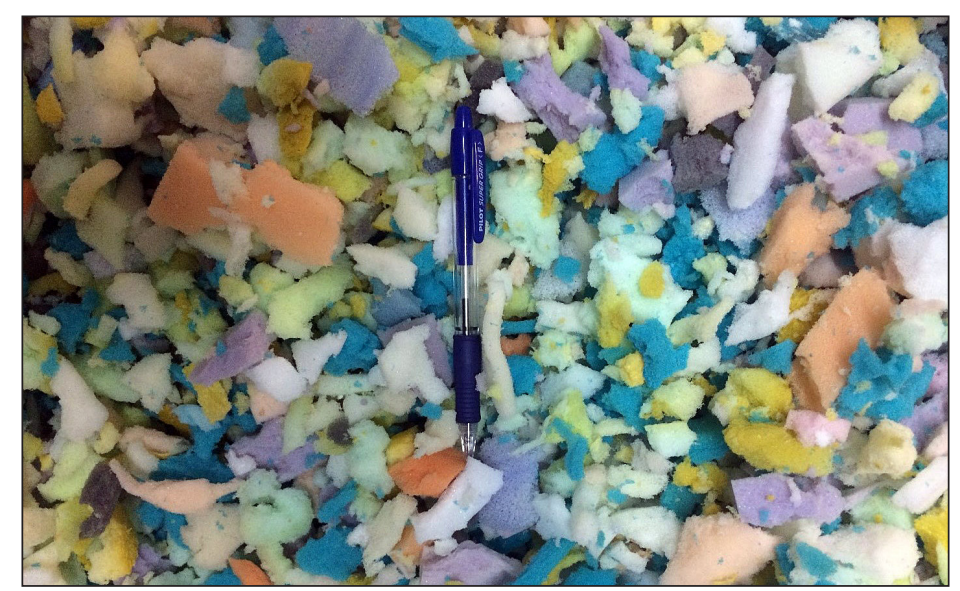

Figure 1. Pieces of polyurethane foam waste used as biofilter filling (phot. E. Dacewicz) 
The experimental filters were sectional models of a vertical flow filter, studied on a semi-technical scale. The experimental model consisted of three identical PVC columns, of $10 \mathrm{~cm}$ in diameter and $100 \mathrm{~cm}$ high. The layers of filling in individual columns were $60 \mathrm{~cm}, 30 \mathrm{~cm}$, and $15 \mathrm{~cm}$ thick. A grate supporting the bed was installed at the bottom of each filter layer. Figure 3 shows a diagram of the column model.

The test sewage was first pretreated in a septic tank and then transferred to a storage tank for further reduction of $\mathrm{BOD}_{5}$ and total suspended solids. The effluents from the storage tank were fed onto the top foam layer, and then flowed down gravitationally. The sewage was dosed onto the model columns with peristaltic pumps started cyclically every hour ( 24 doses per day). Each column in the experimental model was subjected to the same hydraulic loading during one of seven stages that changed every three weeks during five months of the experiment. The hydraulic loading was applied in the following variants: $31.8 \mathrm{~mm} \cdot \mathrm{d}^{-1}$ (II and IV stage), $76.4 \mathrm{~mm} \cdot \mathrm{d}^{-1}$ (I and V stage), $114.6 \mathrm{~mm}^{-1}$ (III and VI stage) and $229.2 \mathrm{~mm}^{-1}$ (VII stage). The acclimation phase of the beds lasted for 1.5 week before the actual experiment. [s-ipiThe pretreated sewage was collected from a separating chamber downstream from the storage tank, and the treated sewage was collected as filtrates from individual columns of the model. The sewage samples underwent physi- cal and chemical analyses for the following indicators of sewage pollution: dissolved oxygen, $\mathrm{BOD}_{5}, \mathrm{COD}_{\mathrm{Cr}}$, total suspended solids, and ammonium nitrogen. The physical and chemical analyses were performed 2-3 times a week, on average, for 8-9 measurement series.

Filter performance was determined based on measured $\mathrm{BOD}_{5}, \mathrm{COD}_{\mathrm{Cr}}$ ammonium nitrogen $\left(\mathrm{N}^{-} \mathrm{NH}_{4}^{+}\right)$, and total suspended solids. The values for these indicators were determined as per relevant standards: EN 1899-1:2002 for $\mathrm{BOD}_{5}$, ISO 6060:2006 for $\mathrm{COD}_{\mathrm{Cr},}$ PN-C-04576-4:1994 for ammonium nitrogen, and EN 872:2007 for total suspended solids.

The statistical analyses were performed with the STATISTICA 12.5 software package. Mean levels of the studied indicators in the sewage collected from specific layers of the filter bed were used in the ANOVA analysis. The values of analyzed sewage pollutants $\left(\mathrm{BOD}_{5}, \mathrm{COD}_{\mathrm{Cr}}\right.$, total suspended solids, and ammonium nitrogen) from individual levels of the filter bed were used as a dependent variable. Before ANOVA, the Grubbs' test for outliers must be performed and the normality of variables distribution must be established, which is then verified with the Shapiro-Wilk test. Significant differences between variations of removed pollutants were verified with an analysis of homogeneity of variances using the Levene's test. In order to establish which intergroup differences in the reduction rate were of the highest sig-

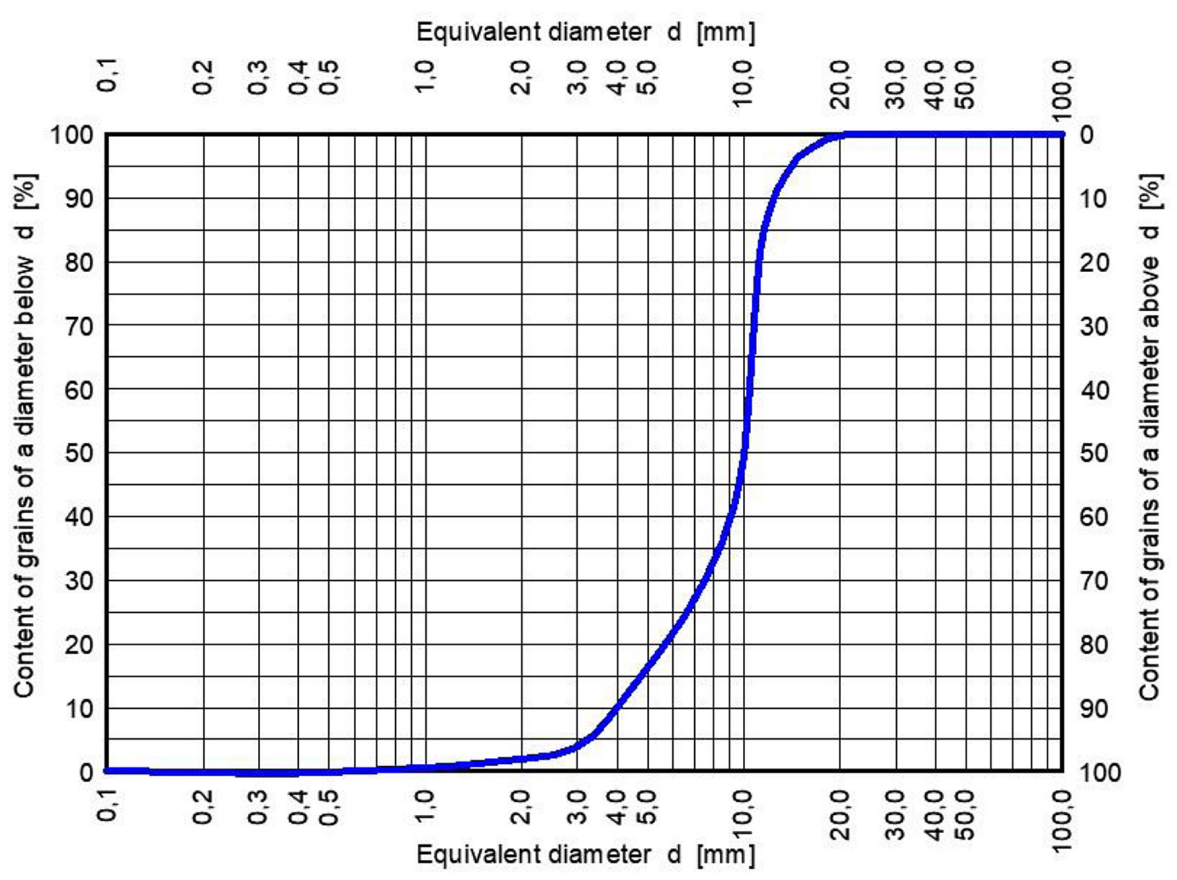

Figure 2. Granulometric curve for filter filling of PUR foam 


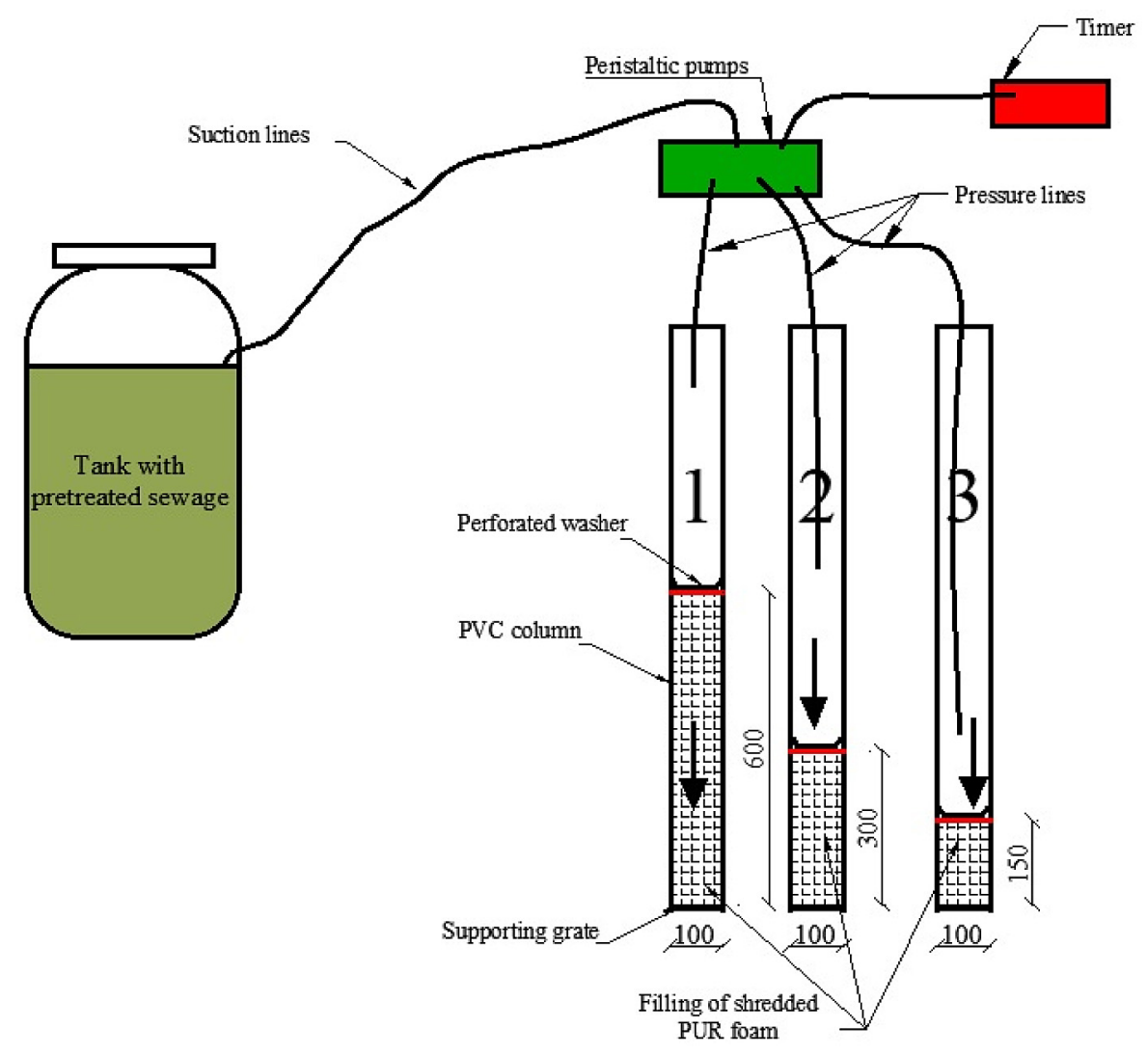

Figure 3. Diagram of a column model

nificance, the non-parametric Kruskal-Wallis test was performed. A difference in means for a given pair of groups was considered significant when the probability value (p-value) was below 0.05 .

\section{RESULTS AND DISCUSSION}

Table 1 presents the basic descriptive statistics for household sewage post the septic tank, supplied to the storage tank and then to the test station. The sewage flowing into the experimental model varied greatly in $\mathrm{BOD}_{5}(\mathrm{WN}=1.03)$. The values of that indicator ranged from $20.0 \mathrm{mgO}_{2} \cdot \mathrm{dm}^{-3}$ to $760.0 \mathrm{mgO}_{2} \cdot \mathrm{dm}^{-3}$. Mean $\mathrm{BOD}_{5}$ was $165.6 \mathrm{mgO}_{2} \mathrm{dm}^{-3}$, and standard deviation reached $170.1 \mathrm{mgO}_{2} \cdot \mathrm{dm}^{-3}$. The quoted values demonstrate a significant variation in quality of supplied sewage, with the spread of $740.0 \mathrm{mgO}_{2} \cdot \mathrm{dm}^{-3}$.

At the highest hydraulic loading, the short stay of sewage in the storage tank did not result in sedimentation of total suspended solids, and thus in the reduction of $\mathrm{BOD}_{5}$. Mean $\mathrm{COD}_{\mathrm{Cr}}$ values for pretreated sewage reached $272.5 \mathrm{mgO}_{2} \cdot \mathrm{dm}^{-3}$. This indicator was more stable than $\mathrm{BOD}_{5}(\mathrm{WN}=0.65)$ and ranged from $98.0 \mathrm{mgO}_{2} \cdot \mathrm{dm}^{-3}$ to $972.0 \mathrm{mgO}_{2} \cdot \mathrm{dm}^{-3}$.
The mean value of $\mathrm{COD}_{\mathrm{Cr}} / \mathrm{BOD}_{5}$ ratio in the sewage fed onto individual columns was 1.64, and this implies the presence of organic pollutants both difficult and easy to degrade in biochemical processes [Henze et al. 2008]. In their study of pretreated sewage in a septic tank [Wąsik and Chmielowski 2013, Wąsik and Chmielowski 2017, Wąsik et al. 2017, Dacewicz et al. 2018] obtained similar mean values of these indicators.

Sewage post the storage tank, in which the effluents from the septic tank underwent additional sedimentation of suspended organic matter, showed low values of total suspended solids. When compared to the values for total suspended solids determined directly after the septic tank, they were lower by $20 \%$, on average. The concentration range for suspended solids fluctuated from $37.0 \mathrm{mg} \cdot \mathrm{dm}^{-3}$ to $293.0 \mathrm{mg} \cdot \mathrm{dm}^{-3}$, while the mean value for this indicator was $93.4 \mathrm{mg} \cdot \mathrm{dm}^{-3}$.

The values of the above-mentioned indicators reported by other authors [Wąsik and Chmielowski 2013, Dacewicz 2018] imply higher concentrations of organic compounds and total suspended solids in sewage directly at an outlet from a septic tank.

The sewage flowing into the experimental model after storage in the storage tank 
Table 1. Quality characteristics of pre-treated sewage flowing into model columns

\begin{tabular}{|l|c|c|c|c|c|c|c|}
\hline \multirow{2}{*}{ Indicator } & \multirow{2}{*}{ Unit } & \multicolumn{6}{|c|}{ Basic descriptive statistics } \\
\cline { 3 - 8 } & & Mean value & Median & $\begin{array}{c}\text { Maximum } \\
\text { value }\end{array}$ & $\begin{array}{c}\text { Minimum } \\
\text { value }\end{array}$ & $\begin{array}{c}\text { Standard } \\
\text { deviation }\end{array}$ & $\begin{array}{c}\text { Coefficient of } \\
\text { variation }\end{array}$ \\
\hline $\begin{array}{l}\text { Dissolved } \\
\text { oxygen }\end{array}$ & $\mathrm{mgO}_{2} \cdot \mathrm{dm}^{-3}$ & 0.22 & 0.14 & 0.90 & 0.01 & 0.21 & 0.98 \\
\hline $\mathrm{COD}_{\mathrm{Cr}}$ & $\mathrm{mgO}_{2} \cdot \mathrm{dm}^{-3}$ & 272.5 & 229.0 & 972.0 & 98.0 & 177.2 & 0.65 \\
\hline $\mathrm{BOD}_{5}$ & $\mathrm{mgO}_{2} \cdot \mathrm{dm}^{-3}$ & 165.6 & 100.0 & 760.0 & 20.0 & 170.1 & 1.03 \\
\hline $\begin{array}{l}\text { Suspended } \\
\text { solids }\end{array}$ & $\mathrm{mg}^{-3} \mathrm{dm}^{-3}$ & 93.4 & 85.0 & 293.0 & 37.0 & 51.5 & 0.55 \\
\hline $\begin{array}{l}\text { Ammonium } \\
\text { nitrogen }\end{array}$ & $\mathrm{mg} \cdot \mathrm{dm}^{-3}$ & 166.3 & 162.8 & 260.5 & 84.8 & 34.1 & 0.21 \\
\hline
\end{tabular}

showed low variation in ammonium nitrogen level $(\mathrm{WN}=0.21$ ). This value ranged from 84.8 $\mathrm{mg} \cdot \mathrm{dm}^{-3}$ to $260.5 \mathrm{mgO}_{2} \cdot \mathrm{dm}^{-3}$, and the mean value was $166.3 \mathrm{mgO}_{2} \mathrm{dm}^{-3}$, which was similar to the value reported by other authors [Wąsik and Chmielowski 2013, Dacewicz 2018b]. When compared to the values reported in other publications for pretreated sewage in the anaerobic UASB reactor [Tawfik et al. 2011, Onodera et al. 2014], the ammonium nitrogen levels in our study were over five times higher.

The data presented in Figure 4 show that the sewage leaving individual columns in the model was characterized by high mean dissolved oxygen (DO) levels, despite very low oxygen content in the sewage supplied to the experimental model (Table 1).

The level of dissolved oxygen in the treated sewage increased with the growing thickness of the filter layer. This indicates a very good oxygen saturation of the filter bed filled with waste upholstery foam. Uemura et al. [2016] analyzed the oxygen mass transfer in new PUR foams placed in a plastic sheath and observed an increase in DO accompanying an increase in foam thickness to $15-30 \mathrm{~cm}$. For these values of the filter layer thickness, the level of dissolved oxygen rose from zero to $7.5 \mathrm{mgO}_{2} \mathrm{dm}^{-3}$, while with further $15 \mathrm{~cm}$ of foam this value reached only $9 \mathrm{mgO}_{2} \cdot \mathrm{dm}^{-3}$. During five months of the experiment, the increase in the hydraulic loading resulted in a drop in the oxygen content in the effluents from individual columns (Fig. 4). Thus, the mean DO value ranged from $3.2 \mathrm{mgO}_{2} \mathrm{dm}^{-3}$ to $4.8 \mathrm{mgO}_{2} \cdot \mathrm{dm}^{-3}$ for the filter bed with $60 \mathrm{~cm}$ thick foam, and was similar to the values obtained for the layer of $30 \mathrm{~cm}\left(2.6 \mathrm{mgO}_{2} \cdot \mathrm{dm}^{-3}\right.$ to $\left.4.8 \mathrm{mgO}_{2} \cdot \mathrm{dm}^{-3}\right)$. For the $15 \mathrm{~cm}$ thick foam, the mean DO concentration

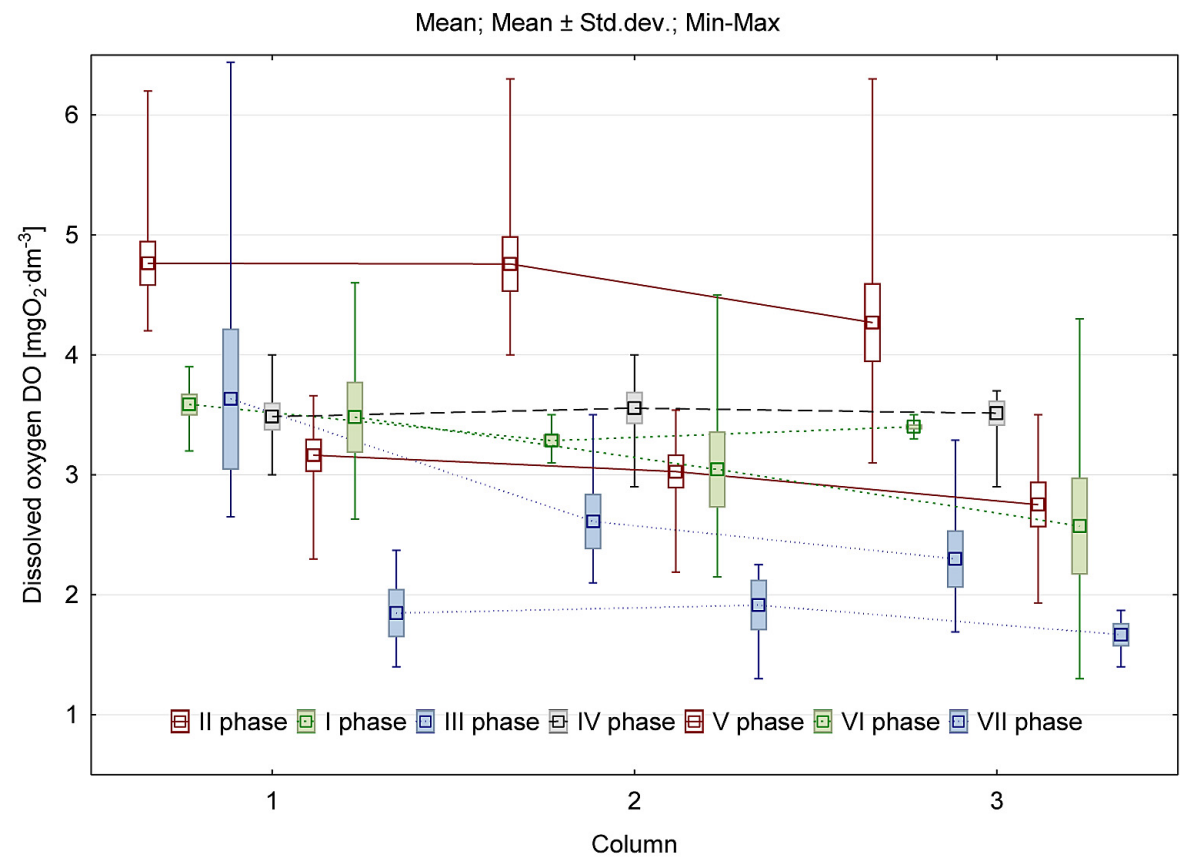

Figure 4.. Box-plot graphs of dissolved oxygen concentrations in sewage from columns 1, 2 and 3 
reached 2.3-4.3 $\mathrm{mgO}_{2} \cdot \mathrm{dm}^{-3}$. Similar results were reported by Onodera et al. [2014], who observed an increase in the dissolved oxygen level in the DHS reactor post UASB reactor, to a level of 3 $\mathrm{mg} \mathrm{O}_{2} \mathrm{dm}^{-3}$ at a distance of $40 \mathrm{~cm}$ from the sewage inlet. Moreover, Tawfik et al. (2011) noticed an increase in DO value from $0.8 \mathrm{mg} \mathrm{O} \cdot \mathrm{dm}^{-3}$ to 2.1-3.1 $\mathrm{O}_{2} \cdot \mathrm{dm}^{-3}$ in the first segment of the DHS reactor during purification of gray sewage.

The results of non-parametric Kruskal-Wallis test for dissolved oxygen levels in the treated sewage at individual stages of the experiment are presented in Table 2. Only at Stage I, partly considered as the period of biofilter acclimation, the p-value was below 0.05 , and this means that the differences in the DO values at the compared stages were significant.

Figures 5-7 present the effectiveness of pollutant removal on individual filters for the analyzed hydraulic loading. Additionally, a part of Stage I of the experimental model operation can be considered as the bed acclimation period. This is implied by a low (17.8-29.6 \%) effectiveness of removal of hardly biodegradable organic compounds. In the discussed period, the $\mathrm{COD}_{\mathrm{Cr}}$ value in the effluents from all three columns was high and exceeded $150 \mathrm{mg} \mathrm{mgO} \mathrm{dm}^{-3}$. This value is accepted by Polish law for treated sewage for treatment plants below 2000 population equivalent (p.e.) [Regulation...2014]. Additionally, during the highest hydraulic loading of $114.7 \mathrm{~mm}^{-1}$ and $229.2 \mathrm{mmd}^{-1}$, at mean $\mathrm{C} / \mathrm{N}$ ratio of 2.8 (III and VI) and 1.9 (Stage VII), we detected higher than acceptable $\mathrm{COD}_{\mathrm{Cr}}$ value in the effluent from household sewage treatment plant. On one hand, the low effectiveness of $\mathrm{COD}_{\mathrm{Cr}}$ removal during the highest loading of the beds could result from a presence of hardly degradable organic compounds, as at that stage the mean $\mathrm{COD} / \mathrm{BOD}$ ratio in raw sewage was 1.9. On the other hand, the high efficiency of removal of easily biodegradable organic compounds indicated an increase in the biomass of heterotrophic bacteria. This could result in blocking of foam pores, leading to a reduced ability for transport of substrates and a drop in the dissolved oxygen levels (Fig. 4) [Tawfik et al. 2010, Uemura et al. 2016].

The authors observed the highest (73.1\%) average $\mathrm{COD}_{\mathrm{Cr}}$ reduction during filtration of pretreated sewage through the $60 \mathrm{~cm}$ thick foam (column 1) at the lowest hydraulic loading of 31.8 $\mathrm{mm} \cdot \mathrm{d}^{-1}$ (Fig. 5). Removal of easily degradable organic substances was fairly independent of the fluctuations in hydraulic loading (Stages II-VI) and reached $90 \%$, on average. The highest $\mathrm{BOD}_{5}$ reduction, at a similar level of $95 \%$, occurred on the beds with the $60 \mathrm{~cm}$ and $30 \mathrm{~cm}$ thick foam at the hydraulic loading of $114.7 \mathrm{~mm} \cdot \mathrm{d}^{-1}$ (Stage III). Column 1, with the increasing hydraulic loading, and consequently oxygen availability, provided more favorable conditions for bed colonization by nitrifying bacteria (Fig. 5). Stage VI contributed to the highest $(71.8 \%)$ reduction of ammonium nitrogen. Over the entire study period, the removal of total suspended solids on the $60 \mathrm{~cm}$ thick foam ranged from $69.2 \%$ (Stage VII) to $86.6 \%$ (Stage III).

For the $30 \mathrm{~cm}$ thick foam, the effectiveness of pollutants removal was more uniform. In column 2 (Fig. 6), the mean rate of the organic compounds removal was the highest for the analyzed thickness levels of PUR waste. At Stage III, $\mathrm{COD}_{\mathrm{Cr}}$ removal reached the level of $93.8 \%$. Similar high values for new fillings were obtained by Tawfik et al. [2011] for the treatment of gray sewage, and Bundy et al. [Bundy et al. 2017] during filtration of household sewage on foam of different thickness. Reduction of easily biodegradable organic compounds on column 2 ranged from $67.7 \%$ (Stage VII) to $94.7 \%$ (Stage III). The effectiveness of ammonium nitrogen removal by the $30 \mathrm{~cm}$ thick foam fluctuated from $46.8 \%$ (Stage VII) to $68.3 \%$ (Stage VI). Column 2 was the least effective in the removal of total suspended solids, which ranged from $74.6 \%$ (Stage IV) to $84.0 \%$ (Stage II).

Elimination of ammonium nitrogen at Stage I depended on the filling thickness, and increased from $42.2 \%$ (Fig. 7 ) to $61.7 \%$ (Fig. 5) with an increase in foam thickness. The columns filled with

Table 2. Kruskal-Wallis test results for dissolved oxygen levels in treated sewage during five months of the experiment

\begin{tabular}{|c|c|c|c|c|c|c|}
\hline \multicolumn{7}{|c|}{ Experiment Stage } \\
\hline I & II & III & IV & V & VI & VII \\
\hline 7.4612 & 2.6678 & 5.4854 & 1.1594 & 2.58 & 3.939 & 1.6886 \\
$p=0.0240$ & $p=0.2635$ & $p=0.0644$ & $p=0.5601$ & $p=0.2753$ & $p=0.1395$ & $p=0.4299$ \\
\hline
\end{tabular}

Statistically significant differences are marked in red 


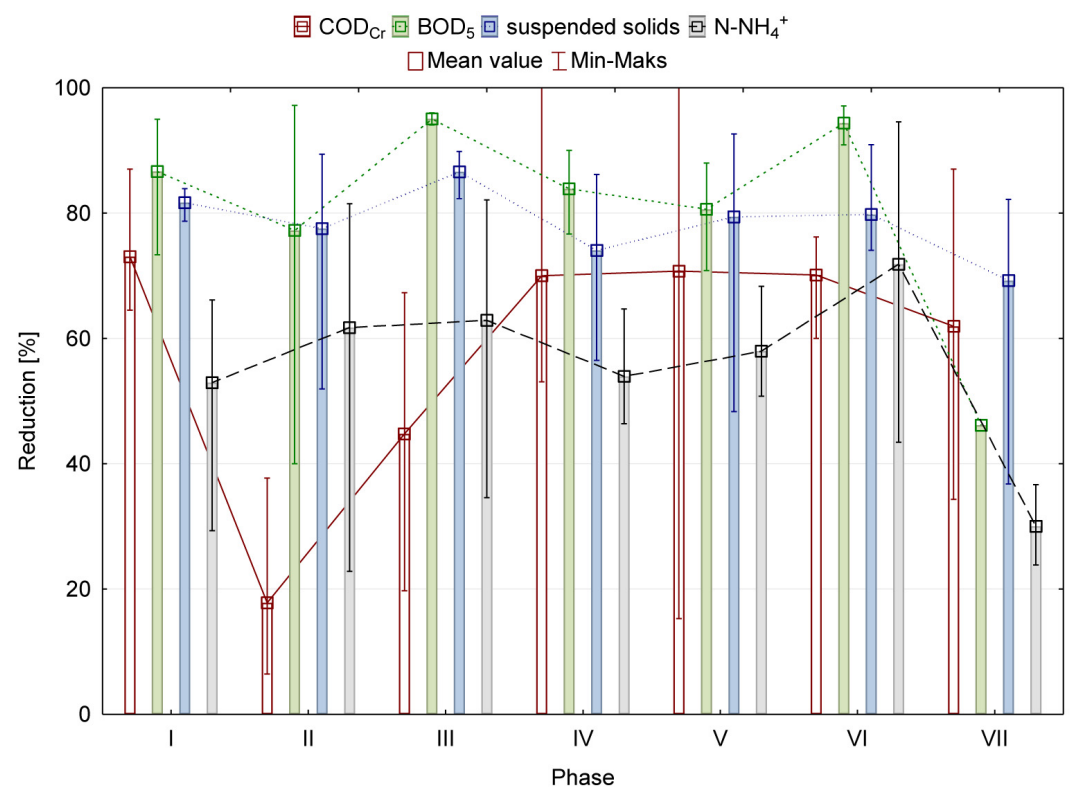

Figure 5.. Reduction of pollution levels in the column 1 for Stages I-VII

the $60 \mathrm{~cm}$ and $30 \mathrm{~cm}$ thick foam removed ammonium nitrogen in the most efficient way (ca. 70\%). High porosity of the polyurethane filling created similar oxygen conditions in these filters and the conditions for mass transfer (substrate, nutrients) which were favorable for growth of nitrifying bacteria [Uemura et al. 2016].

The sewage quality indicators were the most variable in filtrates leaving the column filled with foam of the lowest thickness (column 3). A significant drop in the effectiveness of organic compounds removal on column 3 following an increase in hydraulic loading resulted from a too short time of pollutants trapping on the $15 \mathrm{~cm}$ thick layer of foam. At two initial stages of their operation, $\mathrm{COD}_{\mathrm{Cr}}$ and $\mathrm{BOD}_{5}$ removal reached only $8 \%$ and $34.4 \%$, respectively. The process of ammonium nitrogen removal, with efficiency at a level of $60 \%$, did not depend on the fluctuations in hydraulic loading (Fig. 7). The lowest biomass increase found for this foam thickness resulted in the least effective elimination of organic pollutants - on average, $70.8 \%$ and $89.3 \%$ for $\mathrm{COD}_{\mathrm{Cr}}$ and $\mathrm{BOD}_{5}$, respectively. The greatest rate of organic suspended matter removal on the $15 \mathrm{~cm}$ thick foam can be explained by the unfa-

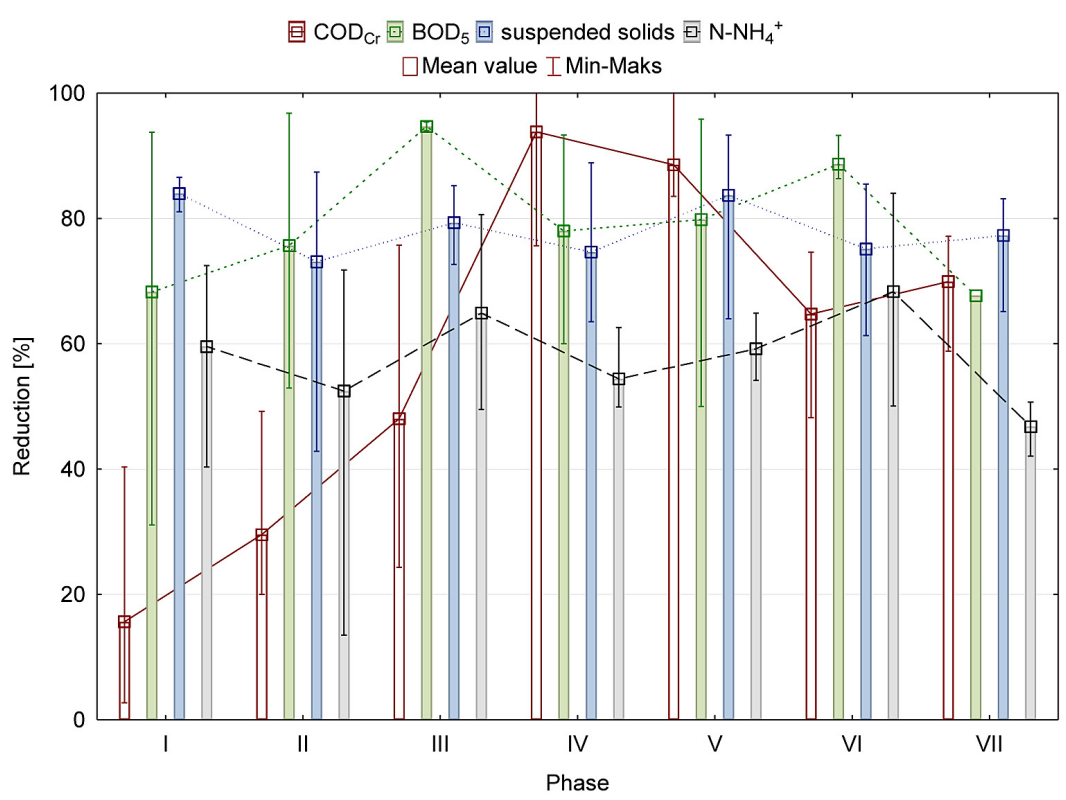

Figure 6. Reduction of pollution levels in the column 2 for Stages I-VII 


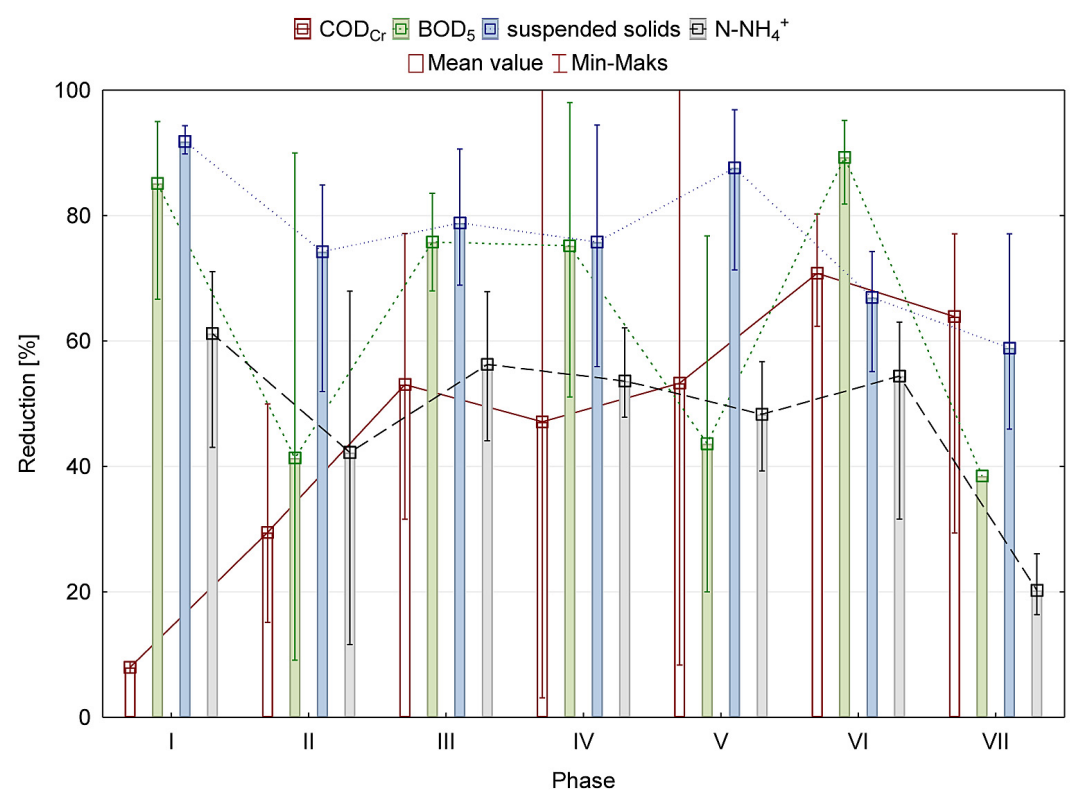

Figure 7. Reduction of pollution levels in the column 3 for Stages I-VII

vorable conditions for biomass development. The biomass present in the filtrate consisted in dead bacteria washed out from the bed. The $\mathrm{COD}_{\mathrm{Cr}}$ to $\mathrm{BOD}_{5}$ ratio in the treated sewage, ranging from 3.8 to 18.7 for $60 \mathrm{~cm}$ bed, from 4.0 to 11.1 for $30 \mathrm{~cm}$ bed, and from 3.1 to 8.1 for $15 \mathrm{~cm}$ bed, indicated only a presence of chemical compounds that could not be degraded with biological methods during five months of the experiment.

Waste polyurethane foam was similarly effective in the treatment of household sewage downstream of the primary sedimentation tank during five months of the experiment, as the DHS technology coupled with the anaerobic UASB reactor. The rate of pollutant removal in a system of new sponges, a so-called "curtain" (DHS of second generation), was $95 \%, 84 \%$ and $61 \%$ for $\mathrm{BOD}_{5}$, COD and ammonium nitrogen, respectively [Ehsas 2011]. In the third and the fourth generation of the DHS system, Tawfik et al. [2011] achieved $\mathrm{COD}, \mathrm{BOD}_{5}$ and ammonium nitrogen reduction at the level of $95 \%, 98 \%$ and $86 \%$, respectively.
In their studies, the $\mathrm{N}-\mathrm{NH}_{4}^{+}$level in the sewage treated in the above-mentioned system was ca. five times lower than in our experiments with PUR waste. Doma et al. [2014] showed that the integrated system UASB-DHS reduced COD by $90 \%$ and BOD by $95 \%$ in process of treatment of catering wastewater.

The last stage of the study investigated a relationship between the bed filter thickness and the differences in the values of $\mathrm{BOD}_{5}, \mathrm{COD}_{\mathrm{Cr}}$, total suspended solids and ammonium nitrogen in the treated sewage leaving individual columns of the experimental model. Table 3 presents the results of non-parametric Kruskal-Wallis test for variables that lack normal distribution and show non-homogeneous variance. The performance of the $30 \mathrm{~cm}$ thick foam was the most stable during five months of the research under the variable hydraulic load. We observed no significant differences in elimination of $\mathrm{BOD}_{5}, \mathrm{~N}^{-\mathrm{NH}_{4}^{+}}$and total suspended solids at significance level $\alpha=0.05$ for this filling thickness.

Table 3. Kruskal-Wallis test results during five months of the experiment (Stages I-VII)

\begin{tabular}{|c|c|c|c|c|c|}
\hline \multirow{2}{*}{ Bed thickness } & \multirow{2}{*}{ Oxygen level } & \multicolumn{4}{|c|}{ Reduction } \\
\hline & & $\mathrm{COD}_{\mathrm{Cr}}$ & $\mathrm{BOD}_{5}$ & $\mathrm{~N}-\mathrm{NH}_{4}^{+}$ & Suspended solids \\
\hline $60 \mathrm{~cm}$ & $\begin{array}{c}29.5075 \\
p=0.00005\end{array}$ & $\begin{array}{c}17.116 \\
p=0.0089\end{array}$ & $\begin{array}{c}9.493 \\
p=0.1477\end{array}$ & $\begin{array}{c}16.1302 \\
p=0.0131\end{array}$ & $\begin{array}{c}4.5259 \\
p=0.6059\end{array}$ \\
\hline $30 \mathrm{~cm}$ & $\begin{array}{c}30.7559 \\
p=0.00003\end{array}$ & $\begin{array}{c}28.9216 \\
p=0.00006\end{array}$ & $\begin{array}{c}4.2732 \\
p=0.6398\end{array}$ & $\begin{array}{c}11.5956 \\
p=0.0716\end{array}$ & $\begin{array}{c}6.5072 \\
p=0.3688\end{array}$ \\
\hline $15 \mathrm{~cm}$ & $\begin{array}{c}35.1651 \\
p=0.00000\end{array}$ & $\begin{array}{c}13.4368 \\
p=0.0366\end{array}$ & $\begin{array}{c}11.0707 \\
p=0.0862\end{array}$ & $\begin{array}{c}20.3743 \\
p=0.0024\end{array}$ & $\begin{array}{c}15.2456 \\
p=0.0184\end{array}$ \\
\hline
\end{tabular}

Statistically significant differences are marked in red 
For the analyzed three levels of thickness, significant differences were found for $\mathrm{COD}_{\mathrm{Cr}}$ removal, and, additionally, for elimination of ammonium nitrogen for $60 \mathrm{~cm}$ bed. This could result from an insufficient level of oxygen saturation and from poorer gas transfer conditions associated with the too high level of foam in column 1. For the lowest foam thickness $(15 \mathrm{~cm})$, the probability value, $p$, exceeded 0.05 only for easily biodegradable compounds, and this means that the differences in $\mathrm{BOD}_{5}$ reduction at compared stages were insignificant.

The data presented above demonstrate a significant correlation between the thickness of the filter bed and the $\mathrm{COD}_{\mathrm{Cr}}$ value in the treated sewage. This relationship does not apply to mean $\mathrm{BOD}_{5}$ values in the treated sewage during five months of the experiment. This may indicate the highest intensity of aerobic processes in the initial layers $(15 \mathrm{~cm})$.

\section{CONCLUSIONS}

1. Removal of carbon compounds on a filter filled with polyurethane waste proceeded with high intensity. The $\mathrm{BOD}_{5}$ elimination rate was high already for the bed with $15 \mathrm{~cm}$ thick filter layer, and amounted to $89.3 \%$ on average. Tawfik et al. [2011] made similar observations for a DHS system coupled with an anaerobic UASB reactor. During an analysis of a sewage profile along the DHS system height they noticed that the upper part of the DHS system (first and second segment) was mainly responsible for COD removal, and this resulted in lower organic loading and less intense competition for oxygen when autotrophic nitrifying bacteria were also present. This meant that nitrification ran smoothly in the successive (third) segment of the DHS system.

2. The elimination rate of easily biodegradable organic substances increased along with the filter layer thickness. The biofilter filled with foam of the greatest thickness, $60 \mathrm{~cm}$ (column 1), was the most effective in $\mathrm{BOD}_{5}$ reduction, which was on average $95.0 \%$. Removal of the organic substances difficult to degrade biochemically, determined by $\mathrm{COD}_{\mathrm{Cr}}$, was the highest in column 2 filled with $30 \mathrm{~cm}$ thick foam.

3. The changes in hydraulic loading (from 31.8 to $\left.229.2 \mathrm{~mm} \cdot \mathrm{d}^{-1}\right)$ resulted in a variable reduction of ammonium nitrogen. The reduction effectiveness depended on the thickness of the filter layer in columns. A high content of an empty fraction in the columns ensured better transfer of gas, and thus had a positive effect on the oxygen conditions within.

4. Total suspended solids were trapped on the studied beds regardless of the filter bed thickness (differences in mean values in effluents from columns 1 and 2 were statistically insignificant).

5. The results of the Kruskal-Wallis test confirm the significant influence of the filter layer thickness on the dissolved oxygen level and the degree of $\mathrm{COD}_{\mathrm{Cr}}$ and $\mathrm{N}-\mathrm{NH}_{4}^{+}$reduction.

6. Due to the favorable conditions for the filter colonization by biomass, column 2 filled with $30 \mathrm{~cm}$ thick foams was the most effective in

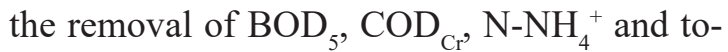
tal suspended solids. For this filter, the average reduction in these pollutants was $94.7 \%$, $93.8 \%, 84.0 \%$ and $68.3 \%$, respectively, under variable hydraulic loading during five months of the experiment.

7. The use of foam trims (with nominal diameters $\mathrm{d}_{10}$ and $\mathrm{d}_{60}$ of $4 \mathrm{~mm}$ and $10 \mathrm{~mm}$, respectively) as biofilter filling supported growth and development of microorganisms to the same high extent as new foam materials installed in plastic sheaths. High porosity of foams $(94.6 \%)$ ensured a concentration of dissolved oxygen at a level sufficient to remove both organic pollutants and ammonium nitrogen from the sewage.

8. Reuse of PUF waste in the form of trims of upholstery foams as elements of a system consisting of a septic tank/storage tank and a vertical flow biofilter, proved to be an efficient way for direct treatment of sewage. This technology, being uncomplicated, easy to control, and cost effective, as opoosed to most of the existing aerobic systems which require additional aeration, offers a highly promising solution for the biological treatment of household sewage.

\section{Acknowledgements}

I would like to thank PhD., Assistant Professor Krzysztof Chmielowski (University of Agriculture, Cracow) for support operating and monitoring the column model. 


\section{REFERENCES}

1. Ali I. 2012. New generation adsorbents for water treatment. Chem. Rev. 112(10), 5073-5091. dx.doi. org $/ 10.1021 / \mathrm{cr} 300133 \mathrm{~d}$

2. Bundy C.A., Wu D., Jong M-C., Edwards S.R., Ahammad Z.S., Graham D.W. 2017. Enhanced denitrification in Downflow Hanging Sponge reactors for decentralised domestic wastewater treatment. Bioresour. Technol. 226,1-8.

3. Chmielowski K., Ślizowski R. 2008. Defining the optimal range of a filter bed's d(10) replacement diameter in vertical flow sand filters. Environ. Protect. Eng. 34(3),35-42.

4. Dacewicz E. 2018a, unpublished results.

5. Dacewicz E. 2018b. Application of selective and porous materials for removal of biogenic compounds and indicator bacteria from domestic wastewater. Acta Sci. Pol. Formatio Circumiectus 17(2), 47-55.

6. Dacewicz E., Chmielowski K. 2018. The importance of media in wastewater treatment. In: Sewage, I. Zhu (ed.) IntechOpen, Rijeka. pp. 35-54. http://dx.doi.org/10.5772/intechopen.75625

7. Dacewicz E., Chmielowski K., Bedla D., Mazur R. 2018. The use of plastic waste in biofilters for domestic sewage treatment. Przemysł Chemiczny, 97(9), 1456-1459, DOI:10.15199/62.2018.9.4 (in Polish).

8. Doma H.S., El-Kamah H.M., Salem A. 2014. Treatment of Catering Wastewater Using a Combination of Up-Flow Anaerobic Sludge Blanket Followed by Down Flow Hanging Sponge Reactor. Life Sci. J. 11(12s), 1104-1111.

9. Ehsas A.F. 2013. Development of low cost community based domestic wastewater for Kandahar city, Afganistan. Ph.D. School of Environment, Resources and Development, Thailand.

10. Gikas P. 2017. Towards energy positive wastewater treatment plants. J. Environ. Manag. 203, 621-629.

11. de Gisi S., Lofrano G., Grassi M., Notarnicol M. 2016. Characteristics and adsorption capacities of low-cost sorbents for wastewater treatment: A review. Sustainable Materials and Technol. 9,10-40.

12. Guo W., Ngo H.H., Dharmawan F., Palmer C.G. 2010. Roles of polyurethane foam in aerobic moving and fixed bed bioreactors. Bioresour. Technol. 101(5),1435-1439.

13. Henze M., van Loosdrecht M.C.M., Ekama G.A., Brdjanovic D. 2008. Biological Wastewater Treatment. Principles, Modelling and Design. IWA Publishing, London, UK.

14. Miyaoko Y., Yoochatchaval W., Sumino H., Banjongproo P., Yamaguchi T., Onodera T., Okadera T., Syutsubo K. 2017. Evaluation of the process performance of a down-flow hanging sponge reactor for direct treatment of domestic wastewater in Bangkok, Thailand. J. Environ. Sci. and Health Part A, 52(10), 956-970. doi: 10.1080/10934529.2017.1324708
15. Onodera T., Yoochatchaval W., Sumino H., Mizuochi M., Okadera T., Fujita T., Banjongproo P., Syutsubo K. 2014. Pilot-scale experiment of down-flow hanging sponge for direct treatment of low-strength municipal wastewater in Bangkok, Thailand. Bioprocess Biosyst. Eng. 37(11), 2281-2287.

16. Onodera T., Tandukar M., Sugiyana D., Uemura S., Ohashi A., Harada H. 2014. Development of a sixth-generation down-flow hanging sponge (DHS) reactor using rigid sponge media for posttreatment of UASB treating municipal sewage. Bioresour. Technol. 152, 93-100.

17. Regulation of the Minister of the Environment of 18 November 2014 on the conditions to be met when discharging sewage into water or soil and on substances particularly harmful to the aquatic environment. Journal of Laws 2014 pos. 1800 (in Polish).

18. Tawfik A., El-Gohary F., Ohashi A., Harada H. 2008. Optimization of the performance of an integrated anaerobic-aerobic system for domestic wastewater treatment. Water Sci. Technol. 58(1), 185-194.

19. Tawfik A., El-Gohary F., Ohashi A., Harada H. 2010. Effect of sponge volume on the performance of downflow hanging sponge system treating UASB reactor effluent. Bioprocess Biosyst. Eng. J. 33(7), 779-785.

20. Tawfik A., Klapwijk A. 2010. Polyurethane rotating disc system for post-treatment of anaerobically pretreated sewage. J. Environ. Manag. 91(5), 1183-1192.

21. Tawfik A., Wahab R.A., Al-Asmer A., Matary F. 2011. Effect of hydraulic retention time on the performance of down-flow hanging sponge system treating grey wastewater. Bioprocess Biosyst. Eng. 34(6), 767-776.

22. Uemura S., Suzuki S., Maruyama Y., Harada H. 2012. Direct treatment of settled sewage by DHS reactors with different sizes of sponge support media. Int. J. Environ. Res. 6(1), 25-32.

23. Uemura S., Okubo T., Maeno K., Takahashi M., Kubota K., Harada H. 2016. Evaluation of Water Distribution and Oxygen Mass Transfer in Sponge Support Media for a Down-flow Hanging Sponge Reactor, Int. J. Environ. Res. 10(2), 265-272.

24. Wąsik E., Chmielowski K. 2013. Effectiveness of domestic wastewater treatment in sand filters with vertical flow with the addition of granular active carbon. Infrastructure and Ecology of Rural Areas 1(3), 7-17. (in Polish)

25. Wąsik E., Chmielowski K. 2017. Ammonia and indicator bacteria removal from domestic sewage in a vertical flow filter filled with plastic material. Ecol. Eng. 106, 378-384. https://doi.org/10.1016/j.ecoleng.2017.05.015

26. Wąsik E., Chmielowski K. 2018. Effectiveness of indicator bacteria removal in vertical flow filters filled with natural materials. Environ. Protect. Eng. (in press)

27. United Nations Children's Fund (UNICEF), World Health Organization (WHO)...2017. Progress on Drinking Water, Sanitation and Hygiene: 2017. (2018): https://www.unicef.org/publications/files/ Progress_on_Drinking_Water_Sanitation_and Hygiene_${ }_{2} 01 \overline{7}$.pdf. (accessed July 21, 2018) 